Ekuitas: Jurnal Pendidikan Ekonomi

Volume 9, Number 1, Tahun 2021, pp. 101-108

P-ISSN : 2354-6107 E-ISSN : 2549-2292

DOI : 10.23887 /ekuitas.v9i1.27583

Open Access: https://ejournal.undiksha.ac.id/index.php/EKU

\title{
Pengaruh Kesadaran Wajib Pajak, Kewajiban Moral, Tingkat Pendidikan dan Kondisi Keuangan pada Kepatuhan Wajib Pajak Kendaraan Bermotor
}

\section{Ni Kadek Ayu Widia1*, I Nyoman Putra Yasa²}

1,2 Universitas Pendidikan Ganesha, Singaraja - Indonesia

\section{A R T I C LE IN F O}

Article history:

Received July, 262020

Received in revised form June, 172021

Accepted June, 172021

Available online June, 28 2021

Kata Kunci:

Kepatuhan wajib pajak, kesadaran wajib pajak, kewajiban moral, tingkat pendidikan, kondisi keuangan.

Keywords:

Education levels, financial condition, moral

obligations, taxpayers' compliance, taxpayer awareness.

\begin{abstract}
A B S T RAK
Penelitiaan ini ditujukan untuk menginvestigasi variabel kesadaran wajib pajak, kewajiban moral, tingkat pendidikan serta kondisi keuangan pada ketaatan dalam wajib pajak. Kantor Bersama Samsat Kabupaten Karangasem-Bali menjadi tempat pelaksanaan penelitian ini dengan 327.256 unit motor roda dua yang masuk dalam data Kantor Bersama Samsat Kabupaten Karangasem-Bali. Dari penggunaan metode accidental sampling sebagai metode dalam menyeleksi sampel maka didapatkan 348 sampel. Kuesioner terpilih sebagai teknik di dalam pengumpulan data. Kuesioner tersebut diisi melalui online lebih khususnya yakni dengan google form agar menghindari bahaya Covid-19. Setelah itu, kumpulan data tersebut diuji secara statistik deskriptif, dilakukan pula pengujian instrumen, pengujian asumsi klasik, serta pengujian hipotesis. Multiple regression analysis menjadi bentuk menganalisis data secara kuantitatif. Adapun uji $t$ serta $\mathrm{R}^{2}$ yang berperan dalam terujinya hipotesis dengan dibantu oleh SPSS version 21 for windows. Hasil temuan penelitian ini menyatakan bahwa kepatuhan wajib pajak kendaraan bermotor roda dua diberi pengaruh secara positif signifikan oleh beberapa variabel diantaranya kesadaran wajib pajak $\left(\mathrm{X}_{1}\right)$, kewajiban moral $\left(\mathrm{X}_{2}\right)$, tingkat pendidikan $\left(\mathrm{X}_{3}\right)$, serta kondisi keuangan $\left(\mathrm{X}_{4}\right)$.
\end{abstract}

\section{A B S T R A C T}

The objective of this present study is to use the variable awereness of taxpayers, moral obligations, education level and financial condition of taxpayer compliance. This study was carried out at the Joint Office of Samsat Karangasem Regency. Population of this study is the taxpayer of two-wheeled motor vehicles registered at the Joint Office of Samsat Karangasem Regency, amounting to 327,256 units. The method of determining the sample is the accidental sampling method and obtained a total sample of 348 respondents. The questionnaire is filled via online, particularly with google form to avoid the danger of Covid-19. Data that has been collected is then tested in advance with descriptive ststisticsl tests, test instruments, test classic assumptions, and proceed with hypothesis testing Quantitative analysis techniques applied in this study are multiple regression techniques. Other hypothesis tests are t test and $\mathrm{R}^{2}$ with SPSS version 21 for windows. Findings of this study indicated taxpayer compliance is influenced by several variables including taxpayer awareness $\left(\mathrm{X}_{1}\right)$, moral obligation $\left(\mathrm{X}_{2}\right)$, education level $\left(\mathrm{X}_{3}\right)$, financial condition $\left(\mathrm{X}_{4}\right)$ positively and significantly.

\footnotetext{
* Corresponding author.

E-mai : widiaayyu123@gmail.com (Ni Kadek Ayu Widia)
} 


\section{Pendahuluan}

Pengalokasian dana agar tetap terjalannya pemerintahan dan pembangunan pemerintah tidaklah sedikit. Salah satunya pendapatan terbesar dan sangat berpengaruh di Indonesia yang berasal dari pajak. Melalui pajak tersebut Pemerintah mampu membiayai pengeluaran dalam rangka pembangunan Nasional. Kekuatan sumber daya negara berasal dari dana tersebut yang dikumpulkan. Pajak berperan sangat besar serta kian dihandalkan, yaitu salah satu penerimaan negara untuk digunakan dalam membangun negara dengan segala biaya pemerintahannya. Kontribusi terbesar yang menyumbangkan pemasukan untuk negara yaitu Pajak yang terlihat juga dari APBN. Sehingga, bertambahnya pengeluaran pemerintah dalam membiayai negara negara akan berdampak pada bertambahnya juga pemasukan negara yang dimana pajak termasuk didalamnya (Yanti, 2018).

Jenis pajak daerah yang berpotensi semakin meningkat penerimaan pajak kendaraan bermotor tahun 2017-2019 mengalami peningkatan serta target sebelumnya sudah terpenuhi sebab terjadi penambahan obyek pajak kendaraan bermotor seiring berjalannya tahun. Pada 2017, terdapat kenaikan penerimaan pajak kendaraan bermotor yang telah ditargetkan yaitu sebesar 45.143.070.554 dan terealisasi sebesar 52.555.045.207 atau yang dipersentasikan sebesar 112,10\%. Pada 2018, terdapat peningkatan realisasi target yang ditentukan yakni 52.890.320.933 dan terealisasi 61.398.402.350 atau yang dipersentasikan sebesar 112.68\%. Dan pada 2019, terdapat pengembangan realisasi dari target yang ditentukan yakni 58.976.366.213, dan terealisasi sebesar 67.412.378.165 atau yang dipersentasikan hanya 110.87\%. Dapat disimpulkan bahwa pada tahun 2017-2019 terjadi peningkatan realisasi dari target yang telah ditetapkan. Bertambahnya kuantitas wajib pajak kendaraan bermotor sudah seyogyanya beriringan pula dengan bertambahnya orang-orang yang taat wajib pajak kendaraan bermotor. Akan tetapi, dalam catatan Kantor Bersama SAMSAT Karangasem-Bali, denda yang terjadi masih dalam kategori sering dan hal terkait bermakna masih banyaknya wajib pajak di Kabupaten Karangasem yang ketaatannya masih lemah untuk memenuhi kewajiban. Hal tersebut bisa terjadi karena tidak dibayarkannya segala kewajiban perpajakan secara tepat waktu sehingga terjadi sanksi administrasi dalam bentuk bunga atau denda.

Penelitian ini didukung oleh teori atribusi. Dimana penelitian ini menggunakan variabel penelitian, kesadaran akan wajib pajak, kewajiban moral, tingkat pendidikan dan kondisi keuangan. Dipaparkannya konsep terkait bagaimana orang bereaksi terhadap kejadian sekitar beserta alasan-alasannya dalam teori atribusi yang dimana alasan tersebut lebih dikenal sebagai dispositional attribution dan situational attribution. Dispositional attribution yang juga diistilahkan sebagai penyebab internal yang berasal dari dalam individu tersebut seperti kepribadian, sudut pandang diri, serta kapabilitas motivasi. Situational atrribution yang juga diistilahkan sebagai penyebab eksternal yang menekankan pada pengaruh lingkungan pada perilaku individual layaknya kondisi sosial, nilai sosial, serta pandangan masyarakat. Dikembangkannya konsep bagaimana manusia menilai dengan cara berbeda bergantung pada hubungan makna dengan suatu perilaku.

Di dalam KBBI, kesadaran didefinisikan sebagai keadaan individual dalam mengetahui, mengerti, dan merasakan sesuatu. Ketika ketentuan-ketentuan yang telah diatur sudah mendapat pengakuan, penghargaan serta diketahui dan diataati oleh masyarakat luas maka kemungkinan terbentuknya kesadaran hukum pajak akan semakin besar. Jika hanya 1 aspek yang terpenuhi semisal orang tersebut hanya tahu ketentuannya, maka dapat diasumsikan bahwa kesadaran hukum orang masuk dalam kategori yang lebih rendah dibandingkan mereka yang tahu, mengakui, menghargai serta mengikuti ketentuan yang ada (Yunita, 2017). Kesadaran didefinisikan sebagai kondisi individual dalam bertindak tanpa dipaksa oleh pihak luar. Kesadaran wajib pajak dimaknai sebagai kondisi wajib pajak yang mengaplikasikan ketiga aspek tersebut secara benar dan sukarela (Wilda, 2015). Pengimplementasian teori atribusi dalam studi ini menyangkut kesadaran wajib pajak sebagai faktor internal sungguh memberi dampak pada ketaatan itu sendiri. Kesadaran wajib pajak bisa berupa keadaan sadar akan pentingnya fungsi pajak dalam membiayai dan menunjang negara, sehingga mereka akan melakukanya dengan tanpa paksaan. Hasil tersebut diperkuat oleh Kemala (2015), Yunita (2017) dan Pramudya (2019) yang memaparkan bahwa patuhnya seseorang dalam Wajib Pajak kendaraan bermotor diberikan dampak yang positif oleh kesadaran Wajib Pajak. Hal tersebut berbanding terbalik dengan penelitian Wilda (2015) \& Chusaeri (2017) kedua hal tersebut tidak berpengaruh satu sama lain. Dari pemaparan diatas, terbentuklahh hipotesis berikut:

\section{$H_{1}$ : Kesadaran Wajib pajak memberi pengaruh positif serta signifikan pada kepatuhan wajib pajak} kendaraan bermotor roda dua

Kewajiban moral memiliki kaitan terhadap nilai moral individu, etika, prinsip hidup, perasaan bersalah yang berbeda-beda sebagai moral yang ada dalam diri tiap individu yang mana menjadi landasan seseorang dalam melaksanakan sesuatu perilaku. Senada dengan hal tersebut, teori atribusi menggambarkan dorongan faktor dari dalam diri seseorang menjadi dasar orang dalam bertindak. Dipaparkannya konsep terkait bagaimana orang bereaksi terhadap kejadian sekitar beserta alasan- 
alasannya dalam teori atribusi. Adapun penyebab internal di dalam teori ini yang secara mengkhusus membahas mengenai aspek prilaku individual. Hubungannya dengan kewajiban moral yakni dalam penentuan perilaku wajib pajak pada pemenuhan kewajiban pajaknya. Adapun penelitian terdahulu yang memaparkan keterkaitan kewajiban moral dengan kepatuhan Wajib Pajak oleh Rahayu (2019), Aryandini (2016) and Artha \& Setiawan (2016) bahwa kedua hal itu mempunyai korelasi yang positif signifikan. Berbanding terbalik dengan hal tersebut, Dewi (2016) memaparkan kepatuhan dalam wajib pajak tak diberi pengaruh kewajiban moral. Dari pemaparan sebelumnya, terbentuklah hipotesis seperti dibawah ini: $\mathrm{H}_{2}$ : Kewajiban Moral memberi pengaruh Positif serta signifikan pada kepatuhan wajib pajak kendaraan bermotor roda dua

Undang-Undang Sistem Pendidikan Nasional No. 20 Th 2003 memaparkan Pendidikan ialah sebuah kesadaran yang direncanakan agar kondisi serta proses belajar yang melibatkan pengembangan potensi siswa secara dapat terwujud sehingga pentingnya kekuatan sprilitual dalam agama, kemampuan mengendalikan diri, kecerdasan, personalitas, akhlak serta kapabilitas lainnya yang dibutuhkan baik secara personal, bangsa dan negara bisa terwujud. Pendidikan menjadi suatu upaya dalam mengembangkan SDM yang diterapkan dengan berurutan dan bertingkat sehingga terbentuknya kualitas yang baik pada tiap individual sehingga akan bermanfaat serta martabatnya pun akan meningkat. Merujuk pada Pasal 14 UU Sistem Pend. Nasional 2003, jenjang pendidikan diawali dengan pendidikan dasar dalam kurun waktu 9 tahun sebagai landasan untuk melanjutkan pendidikan menengah. Jenjang kedua yakni Pendidikan menengah. Stelah menyelesaikan pendidikan menengah, dilanjutkan dengan pendidikan tinggi.

Perilaku, keimanan, kedisiplinan, akhlak yang baik dalam pekerjaan serta nilai lainnya seperti mampu menguasai iptek serta kapabilitas dalam berinteraksi sebagai unsur-unsur yang bisa membuat bangsa menjadi maju dan mandiri bisa diwujudkan melalui pendidikan. Diperlukannya sosialisasi ke khalayak ramai sehingga mereka akan paham dan sadar akan pentingnya mewujudkan kepatuhan wajib pajak. Penyebaran informasii melalui sekolah dan perguruan tinggi bisa menjadi salah satu alternatifnya mengingat dunia pendidikan menjadi tempat untuk memberi pengenalan akan wawasan pajak sehingga sejak dini mereka sadar akan taatnya membayar pajak. Apabila wajib pajak merupakan orang yang cukup berpengetahuan dan memiliki cukup ilmu tentang pajak maka ketaatan mereka akan lebih tinggi dibandingkan mereka yang tidak mendapatkan informasi yang cukup.

Dengan adanya faktor pendukung yaitu tingkat pendidikan akan menciptakan ketaatan dalam membayar pajak, karena sudah seharusnya tingkat Pendidikan berbanding lurus dengan kesadaran dan kepatuhan yang terbentuk secara internal sebagai akibat dari semakin mengertinya orang yang berpendidikan dalam menelaah mana yang benar dan salah. Hasil penelitian terkait didukung oleh Qorina (2015) \& Kakunsi et al. (2017) memaparkan Kepatuhan Wajib Pajak diberi pengaruh secara positif signifikan oleh Tingkat Pendidikan. Berbeda dengan Putri (2016) yang tidak menemukan dampak positif dalam jumlah yang signifikan pada tingkat pendidikan dengan ketaatan dalam wajib pajak. Sedangkan Noerman Syah \& Wati (2017) memaparkan rasa patuh wajib pajak tak dipengaruhi sama sekali oleh tingkat Pendidikan dari wajib pajak. Maka, terbentuklah hipotesis yakni:

\section{$\mathrm{H}_{3}$ : Tingkat Pendidikan memberi pengaruh Positif dan signifikan pada kepatuhan wajib pajak} kendaraan bermotor roda dua

Kondisi keuangan didefinisikan sebagai kapabilitas keuangan seseorang dalam pemenuhan kebutuhan. Kondisikeuangan seseorang bisa dikategorikan amat baik jika kebutuhan primer, sekunder dan tersier nya bisa terpenuhi tanpa dibantu oleh pihak luar seperti halnya pinjaman. Berbeda halnya apabila seseorang tersebut sering meminjam dari sanak saudara, kerabat, maupun bank, maka dapat diinterpretasikan bahwa kondisi keuangannya buruk. Oleh karena itu, terpenuhinya pajak seseorang sangat mungkin dipengaruhi oleh kondisi keuangan (Adhimatra \& Noviari, 2018). Kondisi keuangan yang buruk akan berakibat pada tertekannya seseorang dalam melunasi pajak. Hal ini berujung pada rendahnya ketaatan wajib pajak pada orang-orang yang berada dalam kondisi keuangan yang buruk (Yanti, 2018). Hal ini didukung oleh teori atribusi yang menggambarkan konsep terkait bagaimana orang bereaksi terhadap kejadian sekitar beserta alasan-alasannya. Teori ini juga mengandung penyebab dari dalam diri yang berpengaruh pada sisi perilaku orang yang bersangkutan. Hubungan terhadap kondisi keuangan yakni pada penentuan perilaku wajib pajak agar terpenuhi kewajiban pajaknya. Baiknya kondisi keuangan menjadi faktor internal yang membuat aspek perilaku taat wajib pajak terbentuk dengan baik. Hasil penelitian tersebut dikuatkan oleh Aryandini (2016), Yanti (2018), dan Adhimatra \& Noviari (2018) yang menemukan bahwa patuhnya seseorang dalam membayar pajak erat kaitannya dengan kondisi keuangan. Dari pemaparan diatas, terbentuklah hipotesis seperti dibawah ini:

$\mathrm{H}_{4}$ : Kondisi Keuangan memberi pengaruh positif serta signifikan pada kepatuhan wajib pajak kendaraan bermotor roda dua

Berdasarkan latar belakang yang diuraikan, rumusan masalah penelitian ini yakni: (1) Apakah Kepatuhan Wajib Pajak Kendaraan Bermotor Roda Dua di Kabupaten Karangasem disebabkan oleh 
Kesadaran Wajib Pajak secara positif signifikan?, (2) Apakah Kepatuhan Wajib Pajak Kendaraan Bermotor Roda Dua di Kab. Karangasem dipengaruhi oleh Kewajiban Moral secara positif signifikan? (3) Apakah Kepatuhan Wajib Pajak Kendaraan Bermotor Roda Dua di Kab. Karangasem dipengaruhi oleh Tingkat Pendidikan secara positif signifikan?, dan (4) Apakah Kepatuhan Wajib Pajak Kendaraan Bermotor Roda Dua di Kab. Karangasem dipengaruhi oleh Kondisi Keuangan secara positif signifikan?.

Sehingga, tujuan penelitian ini yakni: (1) Meneliti Pengaruh Kesadaran Wajib Pajak pada Kepatuhan Wajib Pajak Kendaraan Bermotor di Kab. Karangasem, (2) Meneliti Pengaruh Kewajiban Moral pada Kepatuhan Wajib Pajak Kendaraan Bermotor Roda Dua di Kab. Karangasem, (3) Meneliti Pengaruh Tingkat Pendidikan pada Kepatuhan Wajib Pajak Kendaraan Bermotor Roda Dua di Kab. Karangasem, dan (4) Meneliti Pengaruh Kondisi Keuangan pada Kepatuhan Wajib Pajak Kendaraan Bermotor Roda Dua di Kab. Karangasem.

\section{Metode}

Penelitian ini memakai jenis penelitian kuantitatif, yang mana data terkumpul, terolah, tersajikan dan teranalisis secara kuantitatif (angka-angka) dan deskriptif (uraian kalimat) sehingga masalah dapat digambarkan dengan jelas. Kantor Bersama Samsat Kabupaten Karangasem-Bali menjadi tempat pelaksanaan penelitian ini dengan 327.256 unit motor roda dua yang masuk dalam data Kantor Bersama Samsat Kabupaten Karangasem-Bali. Dari penggunaan metode accidental sampling sebagai metode dalam menyeleksi sampel maka didapatkan 348 sampel. Kuesioner terpilih sebagai teknik di dalam pengumpulan data. Kuesioner tersebut diisi melalui online lebih khususnya yakni dengan google form agar menghindari bahaya Covid-19. Setelah itu, kumpulan data tersebut diuji secara statistik deskriptif, dilakukan pula pengujian instrumen, pengujian asumsi klasik, serta pengujian hipotesis. Multiple regression analysis menjadi bentuk menganalisis data secara kuantitatif. Adapun uji $t$ serta $\mathrm{R}^{2}$ yang berperan dalam terujinya hipotesis dengan dibantu oleh SPSS version 21 for windows.

\section{Hasil dan pembahasan}

Pengujian Statistik Deskriptif dari variabel kesadaran wajib pajak ( $\mathrm{X}_{1}$ ) bernilai maksimum 25, minimun 16, serta mean 20,00 dan standar deviasi 2,329. Hal tersebut menunjukkan adanya perbedaan nilai kesadaran wajib pajak pada nilai rerata yakni 2,329. Variabel kewajiban moral $\left(\mathrm{X}_{2}\right)$ bernilai maksimum 24, minimum 14, serta mean 19.39 serta standar deviasi 1,753. Hal tersebut menunjukkan adanya perbedaan nilai kewajiban moral pada nilai rerata yakni 1,753. Variabel tingkat pendidikan $\left(\mathrm{X}_{3}\right)$ memiliki nilai maksimum 1, nilai minimum 0 , dan mean,52, serta standar deviasi,500. Hal tersebut menunjukkan adanya perbedaan nilai tingkat pendidikan pada nilai rerata yakni ,500. Variabel kondisi keuangan $\left(\mathrm{X}_{4}\right)$ bernilai maksimum 25, minimum 14, mean 19,60 dan standar deviasi 2,264. Hal tersebut menunjukkan adanya perbedaan kondisi keuangan pada nilai rerata yakni 2,264. Untuk kepatuhan Wajib Pajak (Y) bernilai maksimum 25, minimum 15 serta mean 20,18 dan berstandar deviasi 2,043. Hal tersebut menunjukkan adanya perbedaan nilai kepatuhan Wajib Pajak pada nilai rerata yakni 2,043. Hasil terkait tergolong baik dikarenakan tiap variabel mempuyai standar deviasi < mean, dengan kata lain penyimpanan data cukup rendah.

Selain uji statistik deskriptif juga menguji validitas. Uji validitas dilaksanakan agar mengetahui sebaik apa instrument penelitian melakukan pengukuran pada hal yang harus diukur (Sugiyono, 2010). Dalam menguji apakah instrument yang dipakai memenuhi persyaratan, menggunakan kolerasi pearson. Apabila signifikan sign. (2-tailed) $<0,05$, tiap pertanyaan dikatakan valid. Sedangkan apabila signifikan sign. (2tailed $)>0,05$, tiap pertanyaan tidak valid. Mengacu pada hasil uji validitas, seluruh variabel memiliki sign. (2-tailed) 0,000 < 0,05 maka pertanyaan kedua variabel dinyatakan valid.

Setelah uji validitas, dilaksanakan uji reliabilitas. Sebuah kuesioner disebut reliabel dan handal jika jawaban responden konstan. Hasil realibilitas menggunakan bantuan SPSS version 21 for windows akan menghasilkan cronbach's alpa. Uji reabilitas memakai rumus cronbach's alpha. Ghozali (2011) memaparkan dasar ketika mengambil keputusan di uji reabilitas yakni bila nilai Cronbach's Alpha >0,60, maka reliabel. Namun jika nilai Cronbach: s Alpha <0,60, maka tak reliabel. Merujuk pada hasil uji reabilitas, nilai Cronbach's Alpha variabel Kepatuhan Wajib Pajak Orang Pribadi (Y) 0,678 serta nilai terkait > 0,60, jadi seluruh pertanyaan reliabel. Di variabel Kesadaran Wajib Pajak (X1) nilai Cronbach's Alpha 0,855 serta nilai terkait > 0,60, jadi seluruh pertanyaan realibel. Di variabel Kewajiban Moral (X2) nilai Cronbach's Alpha 0,538 serta nilai terkait $>0,60$, jadi seluruh butir pertanyaan realibel. Selanjutnya terakhir Kondisi 
Keuangan $\left(\mathrm{X}_{4}\right)$ nilai Cronbach's Alpha sebesar 0,813 serta nilai terkait $>0,60$, jadi seluruh butir pertanyaan reliabel.

Selanjutnya melakukan uji asumsi klasik, diantaranya uji normalitas yang dilaksanakan agar mengetahui apakah pada model regresi, kedua variabel terdistribusi dengan normal atau tidak. Uji normalitas residual yang digunakan yakni uji statistik Non-parameter Kolmogrov Sminor Test (K-S) memakai program SPSS version 21 for Windows. Dasar ketika mengambil keputusan dapat melalui penentuan kenormalan data yang diukur melalui angka probabilitasnya (Asymtotic Significance), jika probabilitas $>0,05$ populasi normal dan jika probabilitas $<0,05$ populasi tak terdistribusi normal. Merujuk pada hasil, nilai statistik Test Statistic Kolmogorov-Sminov 0,463 serta memiliki signifikansi 0,983. Angka signifikansi terkait $>0,05$, jadi data telah terdistribusi dengan normal.

Uji Asumsi klasik selanjutnya yakni uji multikololinearitas. Uji multikololinearitas dilaksanakan agar mengetahhui apakah model regresi berkorelasi antar variabel bebas (Independen) atau tidak. Apabila paa collinearity diagnotic bernilai tolerance variabel independen $\geq 0,10$ serta nilai VIF $\leq 10$ berarti tak terdapat multikolinearitas atau berarti tidak lolos uji tersebut. Berdasarkan uji multikolonearitas yang memperlihatkan hasil hitung nilai tolerance variabel kesadaran wajib pajak, kewajiban moral, tingkat pendidikan serta kondisi keuangan bernilai tolerance $>0,10$ yakni 0,677, 0,897, 0,994, 0,656 dengan kata lain tak terdapat kolerasi antar variabel independent dengan nilai $>95 \%$. Hasil hitung nilai Variance Inflation Factor (VIF) mengindikasikan tak terdapat satu variabel independen dengan nilai VIF > 10, jadi tak terdapat multikolonearitas antara variabel pada model regresi di penelitian ini.

Selanjutnya yaitu uji heteroskedastisitas dengan tujuan mengetahui apakah di model regresi terjadi ketidaksamaan variance residual satu ke lainnya (Ghozali, 2011). Di penelitian ini memakai uji glejser, dengan dasar mengambil keputusan: jika probabilitas signifikan tiap variabel independen $>0,05$, disebut tak heteroskedastisitas. Sedangkan jika probabilitas signifikan tiap variabel independent $<0,05$, disebut heteroskedastisitas. Pada uji heteroskedastisitas, tiap variabel independen tak signifikan secara statistik memberi pengaruh variabel dependen nilai Absolute Residual (AbsRes). Dimana variabel kesadaran wajib pajak mempunyai sign. 0,133, variabel kewajiban moral memiliki sign. 0,113, variabel tingkat pendidikan memiliki sign. 0,088, serta kewajiban kondisi keuangan mempunyai nilai sign. 0,329. Seluruh variabel independen mempunyai probabilitas signifikansi (probabilitas signifikansi $>0,05$ ), jadi model regresi tak heteroskedastisitas.

Tahapan selanjutnya adalah uji hipotesis, yang memakai model regresi berganda. Model tersebut dipakai dalam mengukur kuat atau tidaknya hubungan kedua variabel atau lebih, serta memperlihatkan arah hubungan kedua variabel. Model regresi linier berganda yakni:

Tabel 01. Hasil Analisis Regresi Berganda Kepatuhan Wajib Pajak

\begin{tabular}{|c|c|c|c|c|c|}
\hline \multirow[b]{2}{*}{ Model } & \multicolumn{2}{|c|}{$\begin{array}{c}\text { Unstandardized } \\
\text { Coefficients }\end{array}$} & \multirow{2}{*}{$\begin{array}{c}\begin{array}{c}\text { Standardized } \\
\text { Coefficients }\end{array} \\
\text { Beta }\end{array}$} & \multirow[b]{2}{*}{$\mathrm{T}$} & \multirow[b]{2}{*}{ Sig. } \\
\hline & B & Std. Error & & & \\
\hline 1 (Constant) & 6,050 & 1,133 & & 5,342 & 0,000 \\
\hline Kesadaran Wajib Pajak $\left(\mathrm{X}_{1}\right)$ & 0,326 & 0,046 & 0,372 & 7,170 & 0,000 \\
\hline Kewajiban Moral $\left(\mathrm{X}_{2}\right)$ & 0,174 & 0,053 & 0,149 & 3,314 & 0,001 \\
\hline Tingkat Pendidikan $\left(\mathrm{X}_{3}\right)$ & 0,519 & 0,175 & 0,127 & 2,964 & 0,003 \\
\hline Kondisi Keuangan $\left(\mathrm{X}_{4}\right)$ & 0,201 & 0,048 & 0,223 & 4,232 & 0,000 \\
\hline
\end{tabular}

$$
" Y=6,050+(0,326) X_{1}+(0,174) X_{2}+(0,519) X_{3}+(0,201) X_{4}+\varepsilon "
$$

Sehingga, bisa dimaknai bahwa hasilnya yaitu:

a. Konstanta 6,050 berarti jika variabel kesadaran wajib pajak, kewajiban moral, tingkat pendidikan serta kondisi keuangan bernilai tetap, rerata nilai kepatuhan wajib pajak 6,050 satuan.

b. Koefisien regresi kesadaran wajib pajak 0,326 sehingga bila ada penambahan 1 satuan, kepatuhan wajib pajak bertambah 0,326 satuan.

c. Koefisien regresi kewajiban moral 0,174 sehingga jika ada penambahan 1 satuan, kepatuhan wajib pajak meningkat 0,174 satuan. 
d. Koefisien regresi tingkat pendidikan 0,519 jadi apabila ada penambahan sebesar 1 satuan, sehingga tingkat pendidikan meningkat 0,519 satuan.

e. Koefisien regresi kondisi keuangan sebesar 0,201 berarti apabila ada penambahan kondisi keuangan, sehingga kondisi keuangan meningkat sebesar 0,201 satuan.

Setelah itu, melakukan uji statistik $t$ agar mengeahui sebesar apa pengaruh kedua variabel. Penempatan agar mengetahui hipotesis diterima dan ditolak yakni melalui perbedaan $t_{\text {hitung }}$ serta tabel serta nilai signifikansinya dengan kriteria yaitu: apabila $t_{\text {hitung }}<t_{\text {tabel }}$ serta nilai sginifikansinya $>0,05$, hipotesis tidak diterima. Sedangkan apabila thitung $>$ tabel serta nilai signifikansinya $<0,05$, hipotesisnya diterima. Berikut simpulan yang bisa ditarik:

1. Uji hipotesis pertama $\left(\mathrm{H}_{1}\right)$ menunjukkan variabel $\left(\mathrm{X}_{1}\right)$ memiliki nilai thitung 7,170 serta signifikansi 0,000 . Berarti thitung 7,170 $>$ nilai tabel serta nilai signifikansi $0,000<0,05$. Nilai thitung yang positif serta $>t_{\text {tabel }}$ dan nilai signifikansi $<0,05$, jadi variabel kesadaran wajib pajak $\left(\mathrm{X}_{1}\right)$ berdampak pada kepatuhan Wajib Pajak (Y). Jadi, $\mathbf{H}_{\mathbf{1}}$ diterima.

2. Uji hipotesis kedua $\left(\mathrm{H}_{2}\right)$ menunjukkan variabel kewajiban moral $\left(\mathrm{X}_{2}\right)$ mempunyai nilai thitung 3,314 serta signifikan 0,001. Jadi, $\mathbf{H}_{2}$ diterima dimana thitung 3,314 $>$ ttabel serta nilai signifikansi 0,001 $<0,05$. Nilai thitung yang positif serta $>t_{\text {tabel }}$ serta signifikan $<0,05$, bermakna variabel kewajiban moral $\left(\mathrm{X}_{2}\right)$ berpengaruh pada kepatuhan Wajib Pajak (Y).

3. Uji hipotesis ketiga $\left(\mathrm{H}_{3}\right)$ menunjukkan variabel tingkat pendidikan $\left(\mathrm{X}_{3}\right)$ mempunyai nilai thitung 2,964 serta signifikansi 0,003. Jadi, thitung 2,964 > nilai tabel serta nilai signifikansi $0,000<0,05$. Nilai thitung yang positif serta $>$ ttabel dan nilai signifikansi $<0,05$, jadi variabel tingkat pendidikan $\left(\mathrm{X}_{3}\right)$ berdampak pada kepatuhan wajib pajak (Y). Jadi, $\mathbf{H}_{3}$ diterima.

4. Uji hipotesis keempat $\left(\mathrm{H}_{4}\right)$ memperlihatkan variabel kondisi keuangan $\left(\mathrm{X}_{4}\right)$ memiliki nilai thitung 4,232 serta signifikan 0,000. Jadi, thitung $4,232>$ tabel serta nilai signifikansi $0,000<0,05$. Nilai thitung yang positif serta $>t_{\text {tabel }}$ dan signifikansi $<0,05$, ini berarti variabel kondisi keuangan $\left(\mathrm{X}_{4}\right)$ berdampak pada kepatuhan Wajib Pajak (Y). Jadi, $\mathbf{H}_{4}$ diterima.

Tabel 02. Hasil Uji Koefisien Determinasi Pengaruh Kesadaran Wajib Pajak, Kewajiban Moral, Tingkat Pendidikan dan Kondisi Keuangan Terhadap Kepatuhan Wajib Pajak Kendaraan Bermotor

\begin{tabular}{ccccc} 
Model & $R$ & $R$ Square & Adjusted $R$ Square & Std. Error of the Estimate \\
\hline 1 & $0,612^{\mathrm{a}}$ & 0,374 & 0,367 & 1,625 \\
\hline
\end{tabular}

Adjusted R square dengan nilai koefisien determinasi 0,367 hal tersebut bermakna variasi variabel kesadaran wajib pajak, kewajiban moral, tingkat pendidikan dan kondisi keuangan hanya bisa menerangkan 36,7\% variasi variabel kepatuhan wajib pajak. Sisanya 63,3\% dikarenakan faktor-faktor di luar penelitian yang bisa memberi pengaruh kepatuhan wajib pajak.

Selanjutnya hasil uji statistik $t$ di penelitian ini keempat variabel independen bernilai signifikansi < 0,05 . Variabel kesadaran wajib pajak bernilai signifikansi 0,000 , variabel kewajiban moral bernilai signifikansi 0,001, variabel tingkat pendidikan mempunyai nilai signifikansi 0,003 , dan variabel kondisi keuangan mempunyai nilai signifikan 0,000. Jadi, semua variabel independen memberi dampak signifikan pada variabel dependen.

\section{Pengaruh Kesadaran Wajib Pajak pada Kepatuhan Wajib Pajak Kendaraan Bermotor Roda Dua}

Hasil penelitan menunjukkan bahwa regresi linier berganda memiliki nilai koefisien kesadaran wajib pajak 0,326 yang artinya apabila terdapat penambahan kesadaran wajib pajak 1 satuan, jadi kepatuhan wajib pajak bertambah 0,326 satuan. Uji hipotesis pertama $\left(\mathrm{H}_{1}\right)$ dengan jumlah sampel 348 orang responden mengindikasikan variabel kesadaran wajib pajak $\left(\mathrm{X}_{1}\right)$ bernilai thitung 7,170 serta signifikansi $0,000<0,05$. Nilai thitung yang positif serta $>$ ttabel dan nilai signifikansi $<0,05$ bermakna kesadaran wajib pajak $\left(\mathrm{X}_{1}\right)$ berdampak dengan kepatuhan wajib pajak (Y). Jadi, $\mathrm{H}_{0}$ tidak diterima serta $\mathrm{H}_{1}$ diterima, dengan kata lain kesadaran wajib pajak memberi dampak positif serta signifikansi terhadap kepatuhan wajib pajak. Jadi, kian tinggi kesadaran wajib pajak, kian besar juga kepatuhan wajib pajak menjalankan kewajibannya. Penelitian sebelumnya juga menemukan pengaruh kesadaran wajib pajak pada kepatuhan wajib pajak oleh Kemala (2015) serta Yunita (2017). Berbeda dengan hasil penelitian Wilda (2015) \& Chusaeri (2017) yang menemukan bahwasanya kesadaran wajib pajak tak memberi dampak terhadap kepatuhan wajib pajak. 
Hasil uji hipotesis didukung teori atribusi yang diaplikasikan pada penelitian ini, dimana kesadaran wajib pajak adalah faktor internal yang memberi pengaruh tingkat kepatuhan wajib pajak.

\section{Pengaruh Kewajiban Moral pada Kepatuhan Wajib Pajak Kendaraan Bermotor Roda Dua}

Hasil regresi linear berganda mengindikasikan koefisien regresi kewajiban moral 0,174 dengan kata lain ada penambahan kewajiban moral 1 satuan, jadi kepatuhan wajib pajak bertambah 0,174 satuan. Pengujian hipotesis kedua $\left(\mathrm{H}_{2}\right)$ dengan jumlah sampel 348 responden memperlihatkan bahwa variabel kewajiban moral $\left(\mathrm{X}_{2}\right)$ mempunyai thitung 3,314 > nilai tabel 1,967 serta nilai signifikansi $0,001<0,05$. Nilai $t_{\text {hitung }}$ yang positif serta $>t_{\text {tabel }}$ dan nilai signifikansi $<0,05$ mengindikasikan variabel $\left(\mathrm{X}_{2}\right)$ berpengaruh dengan variabel $(\mathrm{Y})$. Jadi, $\mathrm{H}_{2}$ ditolak dan $\mathrm{X}_{2}$ diterima. Sehingga, kian tinggi kewajiban moral wajib pajak, kian meningkat kepatuhan wajib pajak, demikian pula sebaiknya. Hasil uji hipotesis didukung teori atribusi yang mana sikap seseorang didasari dorongan faktor internal dari diri seseorang dalam melakukan suatu perilaku. Adapun penelitian terdahulu oleh Rahayu (2019), Aryandini (2016), Artha \& Setiawan (2016) memaparkan kewajiban moral memberi dampak positif signifikan pada kepatuhan wajib pajak. Berbanding terbalik dengan Dewi (2016) bahwasanya kewajiban moral tidak memberi dampak terhadap kepatuhan wajib pajak.

\section{Pengaruh Tingkat Pendidikan pada Kepatuhan Wajib Pajak Kendaraan Bermotor Roda Dua}

Koefisien regresi tingkat pendidikan 0,519, jadi ada penambahan tingkat pendidikan 1 satuan, sehingga kepatuhan wajib pajak meningkat 0,519 satuan. Pengujian hipotesis ketiga $\left(\mathrm{H}_{3}\right)$ dengan jumlah sampel 348 responden mengindikasikan bahwa variabel tingkat pendidikan $\left(\mathrm{X}_{3}\right)$ mempunyai thitung 2,964 serta signifikansi 0,003 . Jadi, thitung 2,964 ) $<$ nilai tabel 1,967 serta nilai signifikan $0,003<0,000$. Nilai thitung yang positif serta $>t_{\text {tabel }}$ dan nilai signifikan $<0,05$ bermakna $\left(\mathrm{X}_{3}\right)$ berdampak signifikan pada ( $\mathrm{Y}$ ). Jadi, $\mathrm{H}_{0}$ ditolak serta $\mathrm{H}_{3}$ diterima yang menyatakan tingkat pendidikan memberi dampak positif serta signifikan pada kepatuhan wajib pajak di Kantor Bersama Samsat Kab. Karangasem-Bali. Kian tinggi tingkat pendidikan kepatuhan wajib pajak ketika membayar pajak Samsat akan kian meningkat. Adapun penelitian sebelumnya oleh Qorina (2015) and Kakunsi et al. (2017) memaparkan Tingkat Pendidikan berdampak positif serta signifikan terhadap kepatuhan wajib pajak. Berbeda dengen penelitian Putri (2016) bahwasanya variabel Tingkat Pendidikan memberi dampak positif tak signifikan pada kepatuhan wajib pajak. Sedangkan Noerman Syah \& Wati (2017) menemukan variabel tingkat pendidikan tak berdampak signifikan pada kepatuhan wajib pajak.

\section{Pengaruh Kondisi Keuangan pada Kepatuhan Wajib Pajak Kendaraan Bermotor Roda Dua}

Koefisien regresi kondisi keuangan sebesar 0,201 jadi, ada penambahan kondisi keuangan 1 satuan, sehingga kepatuhan wajib pajak meningkat 0,201 satuan. Pengujian hipotesis keempat $\left(\mathrm{H}_{4}\right)$ dengan jumlah sampel 348 responden mengindikasikan bahwa kondisi keuangan $\left(\mathrm{X}_{4}\right)$ mempunyai nilai thitung 4,232 serta signifikansi 0,000 . Hal terkait berarti 4,232 > nilai tabel 1,967 serta nilai signifikansi $0,000<0,05$. Nilai thitung yang positif serta $>$ tabel dan nilai signifikansi $<0,05$ bermakna variabel kondisi keuangan $\left(\mathrm{X}_{4}\right)$ berdampak dengan kepatuhan wajib pajak (Y). Jadi, $\mathrm{H}_{0}$ ditolak serta $\mathrm{H}_{4}$ diterima, jadi kondisi keuangan berdampak positif serta signifikan pada kepatuhan wajib pajak. Sehingga, kian baik keadaan keuangan wajib pajak, kian besar juga kepatuhan wajib pajak melakukan kewajiban. Hal terkait didukung teori atribusi yakni pemahaman terhadap respon seseorang pada peristiwa di sekitar mereka. Dalam teori atribusi, penyebab internal merujuk kepada aspek perilaku individual. Hasil penelitian selaras dengan Aryandini (2016), Yanti (2018), Adhimatra \& Noviari (2018) yang menemukan bahwasanya kondisi keuangan berdampak positif terhadap kepatuhan wajib pajak.

\section{Simpulan dan Saran}

Bisa ditarik kesimpulan, yaitu Kesadaran Wajib Pajak, Kewajiban Moral, Tingkat Pendidikan, serta Kondisi Keuangan berdampak positif serta signifikan pada Kepatuhan Wajib Pajak. Adapun saran dari peneliti yaitu: Bagi Kantor Samsat Kabupaten Karangasem, agar berupaya dalam mengembangkan kesadaran wajib pajak melalui cara meningkatkan sosialisasi juga penyuluhan untuk masyarakat luas. Berdasarkan hasil adjusted $R$ square didapatkan nilai koefisien determinasi 0,367 berarti variasi variabel kesadaran wajib pajak, kewajiban moral, tingkat pendidikan, dan kondisi keuangan hanya bisa memaparkan 36,7\% variasi variabel kepatuhan wajib pajak. Sisanya 63,3\% dikarenakan faktor-faktor lain di luar penelitian yang dapat memberi pengaruh pada kepatuhan wajib pajak yang teregistrasi di Kantor Bersama Samsat Kabupaten Karangasem-Bali. Bagi peneliti seterusnya bisa menambah faktor-faktor lain agar dapat meningkatkan kualitas penelitian. 


\section{Daftar Rujukan}

Adhimatra, A. A. G. W., \& Noviari, N. (2018). pengaruh kondisi keuangan wajib pajak, kualitas pelayanan fiskus, dan sanksi perpajakan pada kepatuhan wajib pajak Orang Pribadi di Kantor Pelayanan Pajak $\begin{array}{lllll}\text { Pratama Denpasar Timur. E-Jurnal } & & \end{array}$ https://doi.org/10.24843/eja.2018.v25.i01.p27

Artha, K., \& Setiawan, P. (2016). Pengaruh Kewajiban Moral, Kualitas Pelayanan, Dan Sanksi Perpajakan Pada Kepatuhan Wajib Pajak Di Kpp Badung Utara. E-Jurnal Akuntansi, 17(2), 913-937.

Aryandini. (2016). Faculty of Economics Riau University ,. JOMFekom, 4(1), 1960-1970.

Chusaeri, I. (2017). No Title ال التو اصله طفرة على تتخذى جر ائم .الإلكتروني الابتزاز. Universitas Nusantara PGRI Kediri, 01,1-7. http://www.albayan.ae

Dewi, Nyoman Yuli Marlia. (2016). Pengaruh Kewajiban Moral, Kualitas Pelayanan, dan Pengetahuan Perpajakan Pada Kepatuhan Wajib Pajak Dalam Membayar Pajak Kendaraan Bermotor Pada Kantor Samsat Kabupaten Buleleng. JIMAT (Jurnal Ilmiah Mahasiswa Akuntansi Undiksha) Vol: 5 No:2 Tahun 2016.

Ghozali, Iman. (2011). Aplikasi Analisis Multivariate Dengan Program SPSS. Semarang: Badan Penerbit Universitas Diponogoro.

Kakunsi, E., Pangemanan, S., \& Pontoh, W. (2017). Pengaruh Gender Dan Tingkat Pendidikan Terhadap Kepatuhan Wajib Pajak Di Wilayah Kantor Pelayanan Pajak Pratama Tahuna. Going Concern : Jurnal Riset Akuntansi, 12(2), 391-400. https://doi.org/10.32400/gc.12.2.17771.2017

Kemala (2015). Pengaruh Kesadaran Wajib Pajak, Pengetahuan Pajak, Sikap Wajib Pajak dan Reformasi Administrasi Perpajakan terhadap Kepatuhan Wajib Pajak Kendaraan Bermotor. Jurnal Online Mahasiswa Fakultas Ekonomi Universitas Riau, 2(2), 34067.

Pramudya. (2019). Pengaruh Kualitas Pelayanan Publik, Reformasi Administrasi Perpajakan, Pengetahuan Perpajakan dan Kesadaran Wajib Pajak terhadap Kepatuhan Wajib Pajak Kendaraan Bermotor. Journal of Chemical Information and Modeling, 53(9), 1689-1699. https://doi.org/10.1017/CB09781107415324.004

Noerman Syah, A. L., \& Wati, K. (2017). Analisis Faktor - Faktor Yang Mempengaruhi Kepatuhan Wajib Pajak Dalam Membayar Pajak Kendaraan Bermotor ( Studi Empiris Pada Kantor Uppd / Samsat Brebes ). Jurnal AKSI (Akuntansi Dan Sistem Informasi), 1(2), 65-77. https://doi.org/10.32486/aksi.v1i2.119

Putri, L. R. (2016). Pengaruh Motivasi Membayar Pajak Dan Tingkat Pendidikan Terhadap Kepatuhan Wajib Pajak Orang Pribadi. Jurnal Profita Edisi 8 Tahun 2016, 8(2), 1-12.

Rahayu, Puji (2015). Pengaruh Kualitas pelayanan, Kewajiban Moral, dan Sanksi Perpajakan Terhadap Kepatuhan Wajib Pajak Hotel dalam Membayar Pajak Hotel (Studi Kasus Pada Wajib Pajak Hotel di Kota Pekanbaru). Jom FEKON Vol.2 No.2.

Sugiyono, (2013). Metode penelitian Pendidikan Pendekatan Kuantitatif, Kualitatif, dan R\&D. Bandung: Alfabeta.

Qorina. (2015). Pengaruh Tingkat Pendidikan, Tingkat Penghasilan, Tingkat Pemahaman, dan Pekerjaan Wajib Pajak terhadap Kepatuhan Wajib Pajak di Wilayah Kabupaten Sleman Yogyakarta. 53(9), 1689-1699. https://doi.org/10.1017/CB09781107415324.004

Wilda, F. (2015). Pengaruh Kesadaran Wajib Pajak, Pelayanan Fiskus dan Sanksi Pajak Terhadap Kepatuhan WPOP Yang Melakukan Kegiatan Usaha dan Pekerjaan Bebas di Kota Padang. 1-22.

Yanti, W. D. R. (2018). Pengaruh Kualitas Pelayanan, Sanksi Pajak, Dan Kondisi Keuangan Wajib Pajak Terhadap Kepatuhan Wajib Pajak Kendaraan Bermotor (Studi Pada Kantor Bersama SAMSAT Mojokerto). Jurnal Akuntansi UNESA, Vol.3.

Yunita. (2017). Pengaruh Kesadaran Wajib Pajak, Pengetahuan Pajak, Bea Balik Nama, Sanksi Perpajakan Dan Akuntabilitas Pelayanan Publik Pada Kepatuhan Wajib Pajak Kendaraan Bermotor Di Kantor Samsat Wilayah Kabupaten Banyuwangi. JIMAT (Jurnal Ilmiah Mahasiswa Akuntansi S1), 8(2). https://doi.org/10.23887/jimat.v8i2.14386 